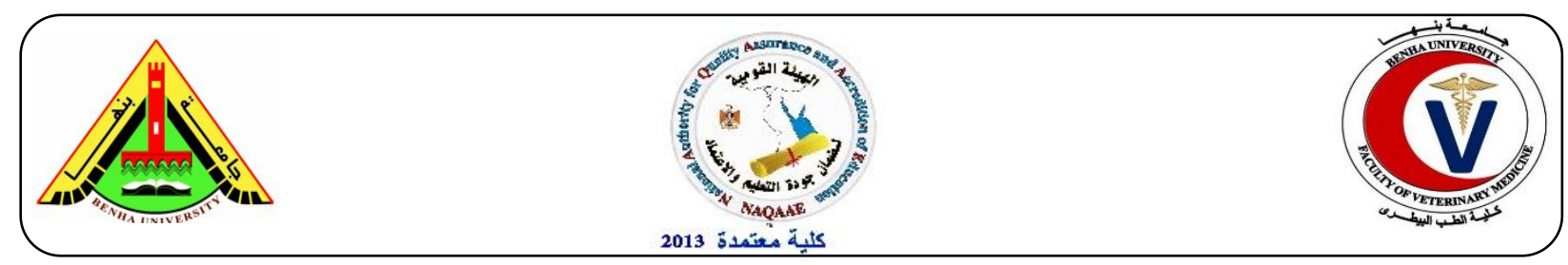

\title{
Some studies on Brucella among camels with reference to isolated strains
}

\author{
Ashraf A. Abd El Tawab ${ }^{1}$, M. A. Agag ${ }^{2}$ R.M. Khoudair, ${ }^{3}$ and Basma Raffat Anwer ${ }^{3}$ \\ Bacteriology, Immunology and Mycology Dept. Faculty of Vet. Med. Benha Univ. ${ }^{1}$ \\ Theriogenology Dept. Faculty of Vet. Med. Benha Univ. ${ }^{2}$ \\ Animal Health Research Institute $\left(\right.$ AHRI) ${ }^{3}$
}

\begin{abstract}
A number of 271 apparently healthy camels of both sexes at different ages were used in this study during a period from April 2016 to May 2017. Samples (271 serum samples, 30 milk samples , 21 tissue specimen and lymph nodes) were obtained from slaughtered camels in different localities (Cairo, Giza, El Sharkyia, El Behira, Matroh). Three serological tests were applied including Buffered Acidified Plate Test (BAPT), modified Rose Bengal Plate Test (mRBPT), and Tube Agglutination Test (TAT). The prevalence of reactors for brucellosis was 9.5\%, 8.8\% and $7.7 \%$ respectively. All samples confirmed by using Rivanol Test (Riv.T) and Immunochromatographic assay (ICA) with $8.5 \%$ and $9.2 \%$ prevalence respectively. All collected milk samples were Negative by MRT (0/30). ICA or (LFA) is highly sensitive, accurate and specific diagnostic assay since it directly detects antibodies of Brucella organism and is considered as rapid confirmatory test.

Culturing from 21 tissue samples and L.N revealed positive isolates as 5/21 (23.8\%). The isolated strain was identified biochemically and by Polymerase Chain Reaction (PCR) with 498 bp and revealed predominance of Brucella abortus in all isolates as 5 (100\%). This work aims at providing an overview on diagnostic investigations, as brucellosis has an economic impact on the production and reproduction in camels.
\end{abstract}

Key words: Brucella, camels, BAPT, mRBPT, TAT, Riv.T, ICA, MRT.

\section{INTRODUCTION}

(http://www.bvmj.bu.edu.eg) (bvmj, 35(1):12-21, SEPT., 2018

Camel brucellosis has been reported in Egypt for the first time by Ahmed (1939) since that time the disease continued to appear with fluctuation in its prevalence. A large number of camels are continuously introduced to Egypt from many African countries; these camels are not tested for brucellosis in quarantines. Egypt imports camels from east Africa to compensate for the gap in meat production. The seroprevalence of brucellosis among camels in the source countries is an indicator for 
potential transboundary brucellosis being introduced to Egypt through untested camels (Sayour, 2015). Camels are affected by any of the three major Brucella species, Brucella abortus, Brucella melitensis and Brucella suis (Rutter and Mack, 1963 and Higgins, 1986). The clinical picture of brucellosis in camels can vary from asymptomatic to abortion (Musa et al, 2008). Dams can develop ovario-bursal adhesions, hydrobursitis, and granulomatous endometritis. Placental retention, infertility, and delayed sexual maturity have also been reported (Musa and Shigidi 2001). Males may suffer from orchitis and arthritis also was recorded accompanied by acute lameness (Musa et al, 2008 and Abbas and Agab, 2002). Brucella organisms were isolated from $20 \quad(87 \%)$ out of 23 serologically positive females camels and typed as B.abortus sero type 7 and B.melitensis sero type 3 (El-Seedy et al., 2000). B. abortus biovar 7 was isolated from camels (Refai, 2003). ICA, Rapid Brucella $\mathrm{Ab}$ Kit is a chromatographic immunoassay proved to be simple, accurate, rapid, does not require specialized training or equipment and economical for the detection of Brucella antibody. A novel concept of Immunochromatographic (ICA) assay which is a simplified version of ELISA make it used as confirmatory test (Montasser et al., 2012).

The present work designed for isolation and identification of Brucella strain by using PCR, elucidate the Prevalence of brucellosis among camels from some localities in Egypt. Moreover, evaluation of the diagnostic efficiency of the commonly used serological tests which including BAPA, Modified RBT, TAT and MRT as screening test and confirmation of positive sera using Riv. test \& ICA.

\section{MATERIAL AND METHODS}

\section{1-samples:}

During a period from April 2016 to May 2017 a number of 271 blood samples were collected from camels of both sexes (Table1) different ages (Table 2) were used in this study from different localities in Egypt for serum separation to be used for serological diagnosis, 30 milk samples were collected from milking she-camels for Milk Ring Test (MRT) and 21 Tissue specimen and lymph nodes from slaughtered camels in Cairo and Giza abattoirs for bacteriological examination (Table 3).

\section{2-Antigens:}

Brucella abortus antigen for BAPAT, mRBPT, TAT, MRT and Riv.T were obtained kindly from the Veterinary Serum and Vaccine Research Institute (VSVRI), Abbassia, Cairo, Egypt.

\section{3-Methods:}

a. Serological tests: Serum samples were tested by different serological tests: modified Rose Bengal plate test (mRBPT) according to Blasco, (1994).Buffered acidified plate antigen test (BAPAT), Tube Agglutination Test (TAT), Milk Ring Test (MRT), Riv. T and ICA acc. to Alton, et al., (1988).

b. Immunochromatographic assay (ICA) (Rapid Brucella Ab Test), from Quicking Biotech Co Ltd. No. 1998, China was applied for Vet. Use Only (Cat No.: W81085), As Brucella-specific antigen a 
LPS extract from a solid culture of Brucella abortus strain 1119-3 was used.

c. Bacteriological examination and Isolation according to FAO/WHO (1986).

d. Polymerase Chain Reaction (PCR) according to QIAamp DNA mini kit instructions

They have specific sequence and amplify a specific product Table (4).

\section{RESULTS}

The obtained results revealed that the prevalence of Brucella reactors among 271 camels by screening serological tests were $26(9.5 \%), 24(8.8 \%)$ and $21(7.7)$ using (BAPAT), (mRBPT), and (TAT) respectively as Table (5) which showed the highest percentage of brucella infection by BAPAT than that mRBPT and $23(8.5 \%), 25(9.2 \%)$ by using Riv.
Test \&ICA as confirmatory tests as Table (6). All milk samples were Negative by MRT 0/30(0\%).

1. ICA test results were read by visual inspection for staining of $\mathrm{C}$ band and $\mathrm{T}$ band

Positive: The presence of both $\mathrm{C}$ band and $\mathrm{T}$ band, no matter $\mathrm{T}$ band is clear or vague.

Negative: Only clear C band appears.

Invalid: No colored band appears in $\mathrm{C}$ zone, no matter whether $\mathrm{T}$ band appears.

2. Bacteriological examination revealed $5 / 21$ isolates $(23.8 \%)$ as Table (7) all 5 isolates were identified biochemically as Brucella abortus.

3. Results of Polymerase Chain Reaction (PCR): revealed 5 isolates with molecular size 498 bp which identified as Br.abortus, DNA as Table (8),

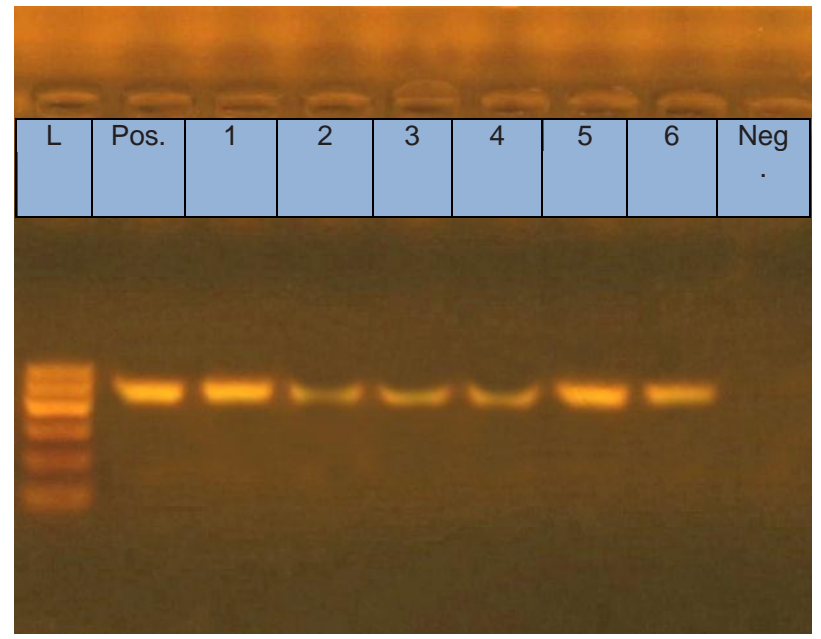

Fig. (1): B. abortus (498 p): Agarose gel electrophoresis of PCR amplification of Br.abortus extracted DNA, Lane L: 100-600bpDNA Ladder. Neg.: Negative control. Pos.: Positive control. Lane 1; positive control .Lane 2:6 Br. abortus (positive). 
Table (1) Number of blood and milk samples collected from different governorate as follows:

\begin{tabular}{llll}
\multirow{2}{*}{ locality } & \multicolumn{3}{c}{ No. of examined camel } \\
\cline { 2 - 4 } & $\begin{array}{l}\text { Total no. } \\
\text { examined }\end{array}$ & females & males \\
\hline Cairo(Al Basatin abattoir) & 100 & 30 & 70 \\
\hline EL Sharkyia & 65 & 50 & 15 \\
\hline El Behira & 50 & 25 & 25 \\
\hline Matroh & 50 & 48 & 5 \\
\hline Giza(Al Warrak abattoir) & 6 & 1 & 117
\end{tabular}

Table (2) Number of examined camels from different localities according to age:

\begin{tabular}{llll}
\multirow{2}{*}{ locality } & \multicolumn{3}{c}{ No. of examined camel } \\
\cline { 2 - 4 } & & $\leq 4-5$ years & $>4-5$ years \\
\hline Cairo (Al Basatin abattoir) & 100 & 50 & 50 \\
\hline EL Sharkyia & 65 & 65 \\
\hline El Behira & 50 & 50 \\
\hline Matroh & 50 & 50 \\
\hline Giza(Al Warrak abattoir) & 6 & & 6 \\
\hline Total & 271 & 50 & 221
\end{tabular}

Table (3) Number of collected tissue and L.N from slaughtered camels:

\begin{tabular}{|c|c|c|c|c|c|c|c|c|c|}
\hline \multirow[t]{2}{*}{ Governorate } & \multicolumn{5}{|c|}{ L.N } & \multicolumn{4}{|c|}{ Tissue } \\
\hline & $\begin{array}{l}\text { Supra } \\
\text { mammary }\end{array}$ & $\begin{array}{l}\text { Retro- } \\
\text { pharyngeal }\end{array}$ & inguinal & mesenteric & uterine & testes & $\begin{array}{l}\text { Umbilical } \\
\text { cord }\end{array}$ & spleen & liver \\
\hline $\begin{array}{l}\text { Cairo } \\
\text { abattoir }\end{array}$ & 2 & 1 & 4 & & 1 & 2 & 1 & 2 & \\
\hline \multirow{2}{*}{$\begin{array}{l}\text { Warrak } \\
\text { abattoir }\end{array}$} & 1 & & 3 & 1 & & 1 & & 1 & 1 \\
\hline & 3 & 1 & 7 & 1 & 1 & 3 & 1 & 3 & 1 \\
\hline Total & & & 13 & & & & & & \\
\hline
\end{tabular}


Table (4): Oligonucleotide primers sequences

\begin{tabular}{|c|c|c|c|c|}
\hline $\begin{array}{l}\text { Target } \\
\text { gene }\end{array}$ & Target & Primers sequences & $\begin{array}{l}\text { Amplified } \\
\text { segment } \\
\text { (bp) }\end{array}$ & Reference \\
\hline $1 \mathrm{~S} 711$ & \multirow[t]{2}{*}{ B. abortus } & $\begin{array}{c}\text { 1S711-specificPrimer } \\
\text { TGC-CGA-TCA-CTT-AAG-GGC-CTT-CAT }\end{array}$ & \multirow[t]{2}{*}{498} & \multirow[t]{4}{*}{$\begin{array}{c}\text { Bricker and } \\
\text { Halling, } 1994\end{array}$} \\
\hline \multirow{3}{*}{$\begin{array}{l}\text { Brucella } \\
\text { generic } \\
\text { specific } \\
\text { gene }\end{array}$} & & $\begin{array}{c}\text { B. abortus-specific Primer } \\
\text { GAC-GAA-CGG-AAT-TTT-TCC-AAT-CCC }\end{array}$ & & \\
\hline & \multirow[t]{2}{*}{ B. melitensis } & $\begin{array}{c}\text { 1S711-specificPrimer } \\
\text { TGC-CGA-TCA-CTT-AAG-GGC-CTT-CAT }\end{array}$ & \multirow[t]{2}{*}{731} & \\
\hline & & $\begin{array}{c}\text { B. melitensis-specific Primer } \\
\text { AAA-TCG-CGT-CCT-TGC-TGG-TCT-GA }\end{array}$ & & \\
\hline
\end{tabular}

Table (5): Seroprevalence of camel brucellosis from different localities using screening tests:

\begin{tabular}{|c|c|c|c|c|c|c|}
\hline \multirow{3}{*}{ Total No. of examined samples } & \multicolumn{2}{|c|}{ BAPAT } & \multicolumn{2}{|c|}{ mRBPT } & \multicolumn{2}{|c|}{ TAT } \\
\hline & \multicolumn{2}{|c|}{ Positive } & \multicolumn{2}{|c|}{ Positive } & \multicolumn{2}{|c|}{ Positive } \\
\hline & No. & $\%$ & No. & $\%$ & No. & $\%$ \\
\hline 271 & 26 & 9.5 & 24 & 8.8 & 21 & 7.7 \\
\hline
\end{tabular}

*the percentages were calculated according to the total number of examined samples

Table (6): Percentage of camel brucellosis from different localities using confirmatory test (Rivanol test and ICA):

\begin{tabular}{rrrrr} 
Test & \multicolumn{2}{c}{ Riv. T } & \multicolumn{2}{c}{ ICA } \\
\cline { 2 - 6 } Total No. of examined samples & \multicolumn{2}{c}{ Positive } & \multicolumn{2}{c}{ Positive } \\
\cline { 2 - 6 } & No. & $\%$ & No. & $\%$ \\
\hline 271 & 23 & 8.5 & 25 & 9.2
\end{tabular}

*the percentages were calculated according to the total number of examined samples 
Table (7): Trial for isolation and identification of Brucella isolated from sero positive slaughtered camels:

\begin{tabular}{lccc}
\multicolumn{1}{c}{ Examined tissue } & No. & $+\mathrm{ve}$ & $* \%$ of $+\mathrm{ve}$ \\
\hline Inguinal L.N & 7 & 2 & $9.5 \%$ \\
\hline Supra-mammary L.N & 3 & 2 & $9.5 \%$ \\
\hline retropharyngeal L.N & 1 & 0 & 0 \\
\hline Mesenteric L.N & 1 & 0 & 0 \\
\hline Uterine L.N & 1 & 0 & 0 \\
\hline Umbilical cord & 1 & 0 & 0 \\
\hline testes & 3 & 1 & $4.8 \%$ \\
\hline Liver & 1 & 0 & 0 \\
\hline Spleen & 3 & 0 & 0 \\
\hline Total No. of isolates & 21 & 5 & $23.8 \%$
\end{tabular}

*the percentages were calculated according to the total number of isolates/ 21

Table (8): Results of Polymerase Chain Reaction (PCR):

\begin{tabular}{cccc} 
Sample code & sample & \multicolumn{2}{c}{ Results } \\
\cline { 3 - 4 } & Positive control & B. abortus & B. melitensis \\
\hline 1 & Testicles & + & + \\
\hline 2 & Superficial inguinal L.N 2 & + & - \\
\hline 3 & Superficial inguinal L.N 1 & + & - \\
\hline 4 & Supra mammary L.N 1 & + & - \\
\hline 5 & Supra mammary L.N 2 & + & -
\end{tabular}

\section{DISCUSSION}

Camel brucellosis can be encountered in all camel rearing countries with exception of Australia. High animal and herd prevalences have been reported from numerous countries, which not only pose a continuous risk for human infection, but also increase the spread of infection through uncontrolled trade of clinically inconspicuous animals (Sprague et al, 2012). Brucellosis in Egypt is still one of the most serious problems facing animal production (Sayed, et al.,2010). The economic impact of brucellosis on camels can be estimated on the basis of losses due to morbidity and mortality and by estimating 
treatment costs (McDermott and Arimi, 2002). Moreover, camels are not known to be primary host of Brucella organisms, but they are susceptible to both $B$. abortus and B. melitensis (Cooper,1991). In Butana area, Eastern Sudan, where camels are reared together with cattle, sheep and goats, (Agab, et al.,1994) isolated many strains of $B$. abortus from lymph nodes of camels serologically positive for brucellosis.

In the present study, the prevalence of Brucella among camels by different serological tests revealed the percentage of positive reactors camels were 26 (9.5\%), 24 (8.8\%), $21(7.7 \%), 23(8.5 \%)$ and 25(9.2\%). using BAPAT, mRBPT, TAT, Riv.T, and ICA respectively as Tables (5) and (6) which agree with (Hegazy, et al., 1998) in Egypt who examined 500 slaughtered female camels for brucellosis. A total of 45 (9\%) camels were positive by RBPT and disagree with (El-Sawalhy, et al., 1996) who examined 500 camels at different abattoirs of Sharkia and Kaluobia governorates and the sero prevalence were $14 \%, 11.6 \%, 7 \%$, $4.4 \%, 2.93 \%$ and $2.29 \%$ using BAPAT , TAT, RBPT , Riv.T, MET and cELISA respectively. While (Horton, et al.,2014) who stated that blood samples were collected from domestic and imported livestock slaughtered at the Muneeb abattoir in central Egypt Antibodies against Brucella spp. in $12(8 \%)$ cattle, one (1\%) buffalo, seven $(4 \%)$ sheep, and one $(10 \%)$ camel.

Lateral flow assay (LFA) could be ideal as a field rapid screening test for developing countries and rural settings, suitable for large- scale screening or presumptive test. Moreover, the high sensitivity and specificity of LFA allows its use as a confirmatory test in combination with RBPAT as a screening assay (Lobna $e t$ al.,2014) also Tharwat El-Shemey (2014) stated that the immuno-chromatographic brucellosis test (ICT) is rapid, card-based test for detection of antibodies directed against Brucella abortus antigen. ICT has $94.44 \%$ sensitivity and $100 \%$ specificity in cattle.

Culturing from 21 tissue samples and L.N collected from slaughter house revealed 5 positive isolates 5/21 (23.8\%), all isolated strain identified biochemically and by Polymerase Chain Reaction (PCR) with 498 bp and revealed predominance of Brucella abortus in all isolates (5)100\% which agree with (Musa et $a l ., 2008)$ In a subsequent abattoir survey of apparently healthy camels, six animals were seropositive, of the six seropositive slaughtered camels, five were shown to have lymph nodes (prescapular and supramammary) infected with brucella (Brucella melitensis biovar 3, two camels; Brucella abortus biovar 6, three camels). and disagree with (El-Sayed et al.,2017) who isolate Brucella melitensis biovar 3 from stomach content of aborted camel fetus.

The obtained Brucella isolates from positive reactors slaughtered camels were examined with PCR for detection and identification of Br.abortus and Br.melitensis. The obtained results revealed 5 isolates with molecular size 498 bp which identified as Br.abortus, DNA. Which agree with Alshaikh et al., (2007) who use Polymerase chain reaction (PCR) to 
diagnose brucellosis in camels using primers that amplified the IS711 locus, 8 samples revealed DNA amplification at around 500 $\mathrm{bp}$, indicating that the organism involved was Brucella abortus.

\section{Conclusion\& Recommendations}

In times of increasing human population, more resources are needed and camels are an ideal asset. The economic impact of brucellosis on camels can be estimated on the basis of losses due to morbidity and mortality and by estimating treatment costs. In turn, we have to improve the laboratory diagnostic methods against brucellosis in camels, ICA or (LFA) is highly sensitive, accurate and specific diagnostic assay since it directly detects antibodies of Brucella organism so is considered as rapid confirmatory test. Camels must be tested or vaccinated against Brucella before introduced to Egypt and also before slaughter and the positive camels must be executed. More hygienic measurers must be taken to protect veterinarians, butchers and workers from infection. National program and surveillance plane recommended to be done in cooperation with neighboring countries and also support of international organization to control zoonotic diseases for public health.

\section{REFERENCES}

Abbas B, Agab H. (2002): A review of camel brucellosis. Prev Vet Med. 55:47-56.

Agab, H., Abbas, B., EL Jack Ahmed, H., and Mamoni, E., (1994) First report on the isolation of Brucella abortus biovar 3 from camel (Camelus dromedarius) in Sudan. Revue Elev. Méd. Vét. Pays. Trop., 47: 361-363.

Ahmed, M. R. (1939): Study on the incidence of contagious abortion in different farm animals in Egypt. Technical Science Bulletin No. 231, Ministry of Agriculture.

Alshaikh, M. A. A.; Al-Haidary, A. I.; Aljumaah, R. S.; Mohammed, O. B.; Al-Korashi, M. M.; Omer, S. A.; El-Nabi, A. R. G.; Hussein, M. F. (2007): First detection of Brucella abortus in camel serum in Saudi Arabia using the polymerase chain reaction. Journal of Applied Animal Research; 2007. 31(2):149-152.

Alton G., Jones L., Angus R. and Veger J. (1988): Techniques for the Brucellosis Laboratory. Institute national de la recherché Agronomique Paris, France.

Blasco,J.M.B. Garin-Bastuji, C.M. Marin, G. Gerbier, J. Fanlo,M.P.J. de Bagues and C.Cau, (1994): Efficacy of different rose Bengal and Complement Fixation antigens for the diagnosis of Brucella melitensis infection in sheep and goat. Vet. Rec., 134:415-420.

Bricker, B. J. and Halling, S. M. (1994): Differentiation of Brucella abortus bv. 1, 2 and 4, Brucella melitensis, Brucella ovis and 
Brucella suis bv. 1 by PCR. J. Clin. Microbiol., 32 (11) : 26602666.

Cooper C. W., (1991): The epidemiology of human brucellosis in a well defined urban population in Saudi Arabia. Journal of Tropical Medicine and Hygiene, 94(6):416-22.

El-Sawalhy, A. A., Montaser, A. M. and Rizk, L. G. (1996): Diagnostic and biochemical evaluations of camel brucellosis. Vet. med. J. Giza. 44 (2): 323- 329.

El-Sayed, A. M.; Sayed-Ahmed, M. Z.; El-Diasty, M. M.; El-Beskawy, M. A.; Shoieb, S. M.; Younis, E. E.(2017): Sero-prevalence of camel brucellosis (Camelus dromedarius) and phenotypic characteristics of Brucella melitensis biovar 3 in Shalateen City, Red Sea Governorate, Egypt African Journal of Microbiology Research; 2017. 11(32):1259-1266.

El-Seedy, F. R.; Radwan, A. I.; ElShabrawy, M. A. (2000): Serological and bacteriological investigations on Brucella infection in one humped camels

FAO/WHO (1986): FAO/WHO Expert committee on Brucellosis 6th Report, WHO. Techn. Rep. Series, 740-101.

Hegazy,A.A.;Elshazly,M.;Wahbah,M.A;Amer,H.
A.(1998): Pathological and serological studies on brucellosis in she camels. Egyptian Jornal of comparative pathology and clinical athology,11:2, 23-32.

Higgins, A. (1986): The Camel in Health and Disease. Bacterial and fungal disease Brucellosis, A book edited by Higgins, A; Bailliere Tindall, London:99-100.

Horton, K. C.; Wasfy, M.; Samaha, H.; Abdel-Rahman, B.; Safwat, S.; Fadeel, M. A.; Mohareb, E.; Dueger, E.(2014): Serosurvey for zoonotic viral and bacterial pathogens among slaughtered livestock in Egypt Vector Borne and Zoonotic Diseases; 2014. 14(9):633-639.

Lobna, M.A. Salem, Khoudair, M.R, and Osman, S.A (2014): Sero diagnosis of brucellosis by using simple and rapid field tests with emphasis on some possible risk factors in humans Dept. of zoonoses. Fac. Of vet. Med., Benha Univ.

McDermott J.J., Arimi S.M. (2002): Brucellosis in sub-Saharan Africa: epidemiology, control, and impact. Vet Microbiol. 90:111-34.

Montaser A.M., Ramadan K.M., Hazem S.S. and Khairy E.A. (2012): Evaluation of immunochromatographic assay for serodiagnosis of Brucella 
among cattle, sheep and goats in Egypt. Global Veterinaria, 8 (5): $512-518$

Musa M.T., Shigidi M.T.A. (2001): Brucellosis in camels in intensive animal breeding areas of Sudan. Implications in abortion and early-life infections. Rev Sci Tech. 54:11-5.

Musa, M.T., Eisa, M.Z., El Sanousi, M., Abdel Wahab, E.M. and Perrett, L. (2008): Brucellosis in Camels (Camelus dromedarius) in Darfur, Western Sudan. Journal of Comparative Pathology. 138: 151-155.

Refai, M. K.(2003): Brucellosis in animals and man in Egypt. Egyptian Journal of Veterinary Science; 2003. 371-31.

Rutter, T.E.G. and Mack, R (1963): Disease of camels, Part1 Bacterial and Fungal diseases, Brucellosis. Vet. Bull. (1963), 33, 3,120.

Sayed, A. S. M.; Ismail, A. A.; Omran, E. M. (2010): Epidemiological study on brucellosis in animals and man in New Valley Governorate. Assiut Veterinary Medical Journal; 2010. 56(126):1-13.

Sayour, A. E.; Elbauomy, E. M.; Hamid, N. H. A.; Abdel-Haleem, M. H. (2015): Selection of a unified standard complement fixation method for nation-wide application to restore interlaboratory harmony to the diagnosis of ruminant brucellosis.Global Veterinaria, 2015. 14(1):83-96.

Sprague, D. Lisa, Al-Dahouk, S. and Neubauer, H. (2012): A review on camel brucellosis: a zoonosis sustained by ignorance and indifference. Pathog Glob Health., 106 (3): 144-149.

Tharwat M. Elshemey and Amir H. AbdElrahman (2014): Evaluation of a Rapid Immunochromatographic Test for Detection of Brucella Abortus Antibodies in Egyptian Cattle Sera and Milk Department of Animal Medicine, Faculty of Veterinary Medicine, Alexandria University. 